\title{
SOME PRELIMINARY NOTES ON THE PHYSICAL PROPER- TIES OF THE SOILS OF THE GANGES VALLEY, MORE ESPECIALLY IN THEIR RELATION TO SOIL MOISTURE.
}

\author{
BY H. M. LEAKE, M.A., F.L.S., \\ Late Scholar, Christ's College, Cambridge.
}

\section{INTRODUCTION.}

IN a stretch of arable lands like those of the Ganges Valley, although damage may be caused by occasional floods, which are sudden and of short duration, the more general, and by far the most serious loss is due to deficiency of moisture of the soil : thus the relation of the soil to soil moisture becomes of more than ordinary importance. Dr Voelcker ${ }^{1}$, in his Report on Indian Agriculture, remarks: "In India the relation of soils to moisture acquires a greater significance than almost anywhere else......" This relation is fundamental, for on it depends the methods for the conservation of soil moisture, for the economical application of irrigation water, and for the treatment of barren and salt lands-all problems of direct interest to agriculturists in the plains of Northern India. The methods for dealing with these problems must be largelyif not entirely-empirical until such time as the behaviour of the soil in its relation to moisture is investigated. The problem in all its various branches is enormous, and in a country in which the seasons follow each other with such rapidity, and vary the one from the other in so marked a manner, it frequently happens that a particular point, if not determined within a period of a few days, must await solution until the following year. It is impossible, therefore, that a series of observations covering a period of barely twelve months should be other than of a purely preliminary nature, and it is in full recognition of this fact that they are here given. Further work will be necessary before it can be

1 "Report on the Improvement of Indian Agriculture," 1893, p. 42. 
considered proved that what is here put forward as a possible explanation of the observed facts is in reality the true explanation. For the present it can merely be stated that the experimental evidence points to the probability of the relation to be indicated.

Although the climate and usual methods of cultivation are matters of common knowledge, it will, for several reasons, be convenient to give a brief survey of the main features of the districts under consideration. These accounts are in no sense exhaustive, and in some cases even, some of the main features are omitted. They will serve, however, to emphasise those points to which the present experiments have reference.

The chief line of enquiry has been that of the relation of soil to soil moisture. Certain preliminary determinations are, however, necessary for the interpretation of results, and since the soil differs so materially from the common types of England, the Continent, and America, on which the major portion of the work on soils has been done, it seemed preferable to re-determine these for the actual soils under consideration ${ }^{1}$. These determinations are here given. One, however, and possibly the most important, namely, mechanical analysis, has to be omitted until such time as opportunity offers for making the necessary determinations. It may be noted in this connexion that in alluvial soils like those under consideration, with little organic matter, and in which the ultimate particles are so minute, mechanical analyses will in all probability prove of more than ordinary importance.

Weather: The main features of the weather are best considered under the three separate headings of (1) Rainfall, (2) Temperature, and (3) Humidity.

Ruinfall. In addition to indicating the essential characteristics of the hormal season, the following table notes the peculiarities of the particular season under consideration :-

1 For similar reasons the references to the somewhat bulky literature which bas been consulted have been omitted. 
(1) Rainfall.

\begin{tabular}{|c|c|c|c|c|}
\hline & \multicolumn{2}{|c|}{ Average ${ }^{1}$} & \multicolumn{2}{|c|}{$\begin{array}{l}\text { Actual figures for period } \\
\text { ander observation? }\end{array}$} \\
\hline & $\begin{array}{l}\text { Rainfall in } \\
\text { inches }\end{array}$ & $\begin{array}{l}\text { No. of rainy } \\
\text { days }\end{array}$ & $\begin{array}{l}\text { Rainfall in } \\
\text { inches }\end{array}$ & $\begin{array}{l}\text { No. of rainy } \\
\text { days }\end{array}$ \\
\hline $\begin{array}{l}\text { April } \ldots \ldots \ldots . . \\
\text { May } \ldots \ldots \ldots . .\end{array}$ & $\begin{array}{l}0.69 \\
2 \cdot 59\end{array}$ & 6.3 & $\begin{array}{l}0.00 \\
0.35\end{array}$ & $\left.\begin{array}{l}0 \\
1\end{array}\right)=2$ \\
\hline $\begin{array}{l}\text { June } . . . . . . . \\
\text { July ........ } \\
\text { August ...... } \\
\text { September... } \\
\text { October ...... }\end{array}$ & $\begin{array}{r}7 \cdot 66 \\
12 \cdot 13 \\
12 \cdot 24 \\
9 \cdot 33 \\
2 \cdot 80\end{array}$ & $49 \cdot 4$ & $\begin{array}{l}3 \cdot 20 \\
5 \cdot 65 \\
9 \cdot 45 \\
3 \cdot 35 \\
4 \cdot 20\end{array}$ & $\left.\begin{array}{r}5 \\
2 \\
12 \\
10 \\
6\end{array}\right) 35$ \\
\hline $\begin{array}{l}\text { November ... } \\
\text { December ... }\end{array}$ & $\begin{array}{l}0 \cdot 07 \\
0.11\end{array}$ & 0.5 & $\begin{array}{l}0.00 \\
0.00\end{array}$ & $\left.\begin{array}{l}0 \\
0\end{array}\right\} 0$ \\
\hline $\begin{array}{l}\text { Jannary...... } \\
\text { February ... }\end{array}$ & $\begin{array}{l}0.65 \\
0.45\end{array}$ & $2 \cdot 4$ & $\begin{array}{l}0.35 \\
0.10\end{array}$ & $\begin{array}{l}1\} 2 \\
1\}\end{array}$ \\
\hline March ...... & $0 \cdot 37$ & - & $0 \cdot 10$ & 1 \\
\hline Total...... & $49 \cdot 09$ & $58 \cdot 6$ & $26 \cdot 75$ & 39 \\
\hline
\end{tabular}

1 From Indian Weather Review, 1902.

2 Author's determinations.

A sharp division into a period of rains-June to October-and a dry period-October to June-is the chief characteristic. The rainfall during the dry period is far too little to support growth in itself. The growth which takes place throughout the greater portion of the year is therefore dependent on the moisture which the plant can derive from the soil. The particular year under consideration is characterised by the lightness of the monsoon rains. This is a factor which must be taken into consideration in considering the values given below; but it seems improbable that the conclusions here drawn will be rendered invalid on this account.

(2) Temperature $\left({ }^{\circ} \mathrm{F}\right.$.).

\begin{tabular}{|c|c|c|c|c|c|c|c|c|c|c|c|c|}
\hline & Jan. & Feb. & Mar. & Apr. & May & June & July & Aug. & Sept. & Oct. & Nov. & Dec. \\
\hline Maximum ... & $72 \cdot 7$ & $76 \cdot 8$ & $87 \cdot 9$ & $96 \cdot 1$ & $95 \cdot 6$ & $92 \cdot 4$ & $89 \cdot 5$ & $88 \cdot 5$ & $88 \cdot 3$ & $86 \cdot 7$ & $81 \cdot 3$ & $74 \cdot 5$ \\
Minimum ... & $52 \cdot 1$ & $54 \cdot 4$ & $62 \cdot 9$ & $71 \cdot 9$ & $76 \cdot 3$ & $79 \cdot 2$ & $79 \cdot 8$ & $79 \cdot 3$ & $78 \cdot 8$ & $73 \cdot 1$ & $62 \cdot 0$ & $53 \cdot 7$ \\
\hline
\end{tabular}


The above table, giving the monthly means of the maximum and minimum temperature, illustrates the main features with regard to the temperature. If this table be compared with that already given for the rainfall it is seen that there are three strongly-marked seasons which may be arranged as follows:-

(1) Cold weather......mid-October to March-low temperature, dry.

(2) Hot weather .......March to mid-June-very hot and very dry.

(3) Rains .............mid-June to mid-October-hot and wet.

\section{(3) Humidity.}

The table given below' simply emphasises the conditions which are prevalent during the hot weather :-

\begin{tabular}{|c|c|c|c|c|c|c|c|c|c|c|c|}
\hline Jan. & Feb. & Mar. & Apr. & May & June & July & Aug. & Sept. & Oct. & Nov. & Dec. \\
\hline 71 & 63 & 54 & 52 & 62 & 76 & 83 & 84 & 82 & 75 & 70 & 73 \\
\hline
\end{tabular}

The Relation of the Soil to Crops. It is not proposed to do more than touch upon this subject; and the point that it is most desired to bring out is best indicated in the case of indigo. In Behar, indigo is commonly sown in early March, when, from the table of rainfall, it will be seen that over four and a half months of practically rainless weather have preceded the time of sowing. Nevertheless, seed placed not an inch below the surface and without irrigation, will germinate. Nor is this the only point, for the young plant is capable of living and growing throughout the three intensely hot and dry months immediately following. Frequently this period passes without a drop of rain, and the plant is subjected during the day to the scorching west winds that are prevalent at this season.

Some idea of the conditions to which the young plant is subjected is given in the following table of soil temperatures:-

1 From Indian Weather Review, 1902.
2 From Indian Weather Review, 1896. 
Soil Temperature $\left({ }^{\circ} \mathrm{F} .\right)^{1}$.

\begin{tabular}{|c|c|c|c|c|}
\hline & Surface & 2 inches & 6 inches & 12 inches. \\
\hline $\begin{array}{l}\text { Germinative period }:- \\
2 \text { p.m. March } 20 \text { th }\end{array}$ & 121 & 86 & $73 \cdot 5$ & $69 \cdot 8$ \\
\hline $\begin{array}{l}\text { Average for week }- \\
2 \text { p.m. March } 17 \text { th-March 23rd }\end{array}$ & 117 & $84 \cdot 5$ & 72 & 69 \\
\hline 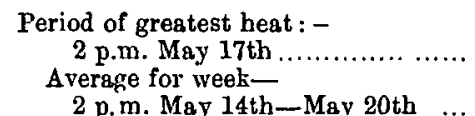 & $143 \cdot 5$ & 102 & 91.5 & 86 \\
\hline
\end{tabular}

A soil, in which not only will seed germinate, but which will support the young plant throughout the protracted period of intense heat and drought, must bear some peculiar property in its relation to moisture.

Methods of Cultivation. Here again the methods of indigo cultivation best indicate the desired points. In the case of this crop the cultivation is most thorough. Briefly, it is as follows:-

The land is thoroughly ploughed two or three times about the middle of October (immediately after cessation of the rains).

If the land be at all "heavy," the clods of earth are, in addition, thoroughly broken by hand, and in this way the surface soil is rendered exceedingly fine. It is then subjected to a process of compacting by means of a maira, a native implement which takes the place of a roller, and consists of a flattened $\log$, to the two ends of which bullocks are yoked. The land is thus compacted at frequent intervals until the sowing period in early March. The moisture is by this time drawn up to the surface, and the seed is drilled in and pressed home by passing the maira again over the field. Germination takes place in 7-10 days. This method is entirely empirical on the part of the cultivator, but it seems worthy of some enquiry and explanation, for it is a remarkable fact that so much moisture can be brought to the surface in this way by the single process of compacting.

General Physical Properties. The soils which form the subject of the present note occupy an area of considerable extent, covering as they do a stretch of country some 800 miles in length, with a breadth varying from 50 to 150 miles. Throughout this area there is an unbroken stretch of alluvial lands, traversed by numerous rivers, which, after

1 Author's determinations. The complete series will be found in the "Report of the Dalsiugb Serai Research Station, 1905." 
leaving the hills, have a fall of between 6 and 9 inches in the mile. The beds of these rivers are some 20 feet below the general level of the surface, which latter extends for mile upon mile in a slightly undulating manner. The undulations are, however, very slight, and rarely reach a value of 10 feet. The depth of alluvial soil is, throughout the area, very considerable, and over the entire area extends below the level of the ground water. In texture the soil is remarkably fine, and broken only by stretches of a calcareous deposit known as kankar. These deposits occur quite irregularly, and at various depths. In the absence of mechanical analyses it is impossible to give any accurate measure of the size of the soil particles. It is known ${ }^{2}$ that $97-98$ per cent. of the soil will pass through a sieve with 80 meshes to the linear inch. A more abstract, but, perhaps, a more lucid, idea will be given, if it is said that the ultimate particles are so minute that, if rubbed dry between the fingers no sensation of "grit" is produced. Until definite mechanical analyses are made this description must suffice. As is usual with alluvial soils, considerable variation of character occurs, and the changes are frequently abrupt and quite irregular. Thus beds of clay occur which rapidly die out and may be replaced by a fine, light sand or by some intermediate type; but the point that it is desired to emphasize is, that all these variations take place within the limits of size of the soil particles above given.

\section{(2) Scope and Methods of the Investigation.}

At the commencement, the scope of the investigation was strictly limited to the determination of the moisture and temperature of the soil for the normal conditions under which indigo is sown, with the ultimate object of tracing some means of rendering these as favourable as possible; for, although the crop is normally sown at this season, a fact which, in itself, proves that germination is, as a whole, satisfactory -it is undoubtedly the case that a considerable annual loss takes place from failure in the germination or from subsequent withering due to lack of moisture.

It was soon found, however, that the moisture conditions were subject to such daily and seasonal variations that the scope had to be widened considerably to include a study of the causes which gave rise to these variations. Here, again, it was found impossible to draw a limit, and it became necessury to stidy in outline the general question

1 Determination made by author. 
of the relations of the soil moisture to the ground water, and of this, again, to the free water surfaces. It was found, for instance, that a considerable movement of the soil moisture was taking place, and that this movement was of such a nature that it must constitute a severe drain upon the reserve supply of ground water. A daily record of the fluctuations of a well was therefore instituted. The fluctuations so disclosed seemed barely sufficient to account for the observed facts, and a further comparison was made between the well level (level of ground water) and that of the free water surfaces (river, etc.). The gradually expanding scope of the investigation, taken in conjunction with the short period devoted to the enquiry, necessarily led to a somewhat limited collection of data. They, however, point to the probability of several hitherto unrecognised conditions-possibly peculiar to these soils-the recognition of which, it is hoped, may help to a solution of some of the problems connected with them.

Methods. As the general texture of these soils admits of the employment of somewhat unusual methods in the determination of the various properties now to be considered, those methods finally adopted must now be considered in some detail.

Samples were all taken by means of an iron cylinder about $4 \frac{1}{2}$ inches in diameter, fitted loosely with an iron piston, which allowed the cylinder to be driven in to a depth of 8 inches exactly. The soil to one side of the cylinder is then removed, and the 8 inches column of soil isolated by the insertion of a khurpa (a flat trowel), and removed to the laboratory.

Soil moisture is now determined in the following manner:-In a cylinder of the above diameter the soil can be readily removed by means of the piston without appreciable compression of the superficial layers. One inch (the eighth inch) is first removed, and the soil rapidly and thoroughly mixed in a mortar. From this mixed soil approximately 10 grams is removed into a small glazed porcelain dish, which has been previously dried and weighed, and the weight accurately determined. A second sample, similar to the first, is taken in like manner.

A second inch is now removed and duplicate samples taken of it, and this process is repeated with each of the superficial eight inches contained in the original sample. This method of duplicate determination, therefore, gives 16 samples. The series of dishes is now transferred to a water-oven at $100^{\circ} \mathrm{C}$, which is maintained at that temperature for from $4 \frac{1}{2}$ to 5 hours. The dishes are then removed to 
a desiccator, cooled and weighed, after which they are again heated for 3 hours, and again cooled and weighed.

With regard to this procedure the following points may be noted. It is a procedure which relies solely on the minute size of the soil particles for its accuracy and practicability. That remarkably accurate results are obtainable will be apparent from the figures noted throughout this paper. It will be sufficient to give here two exarnples of the degree of accuracy obtainable.

\section{Degree of Agreement between Samples.}

The following figures are chosen to show the range of accuracy obtainable, and are typical of the degree of error admitted:-

\begin{tabular}{|c|c|c|c|c|c|c|}
\hline & \multicolumn{6}{|c|}{ Weight of moisture per 100 grams dry weight of soil } \\
\hline & 1 & 2 & $\mathbf{3}$ & 4 & 5 & 6 \\
\hline $\begin{array}{c}\text { Sample No. } 1 \ldots \\
, \quad \text { No. } 2 \ldots\end{array}$ & $\begin{array}{l}17 \cdot 31 \\
17 \cdot 31\end{array}$ & $\begin{array}{l}14 \cdot 84 \\
14 \cdot 92\end{array}$ & $\begin{array}{l}12 \cdot 02 \\
12 \cdot 11\end{array}$ & $\begin{array}{l}16 \cdot 64 \\
16 \cdot 55\end{array}$ & $\begin{array}{l}19 \cdot 90 \\
20 \cdot 12\end{array}$ & $\begin{array}{l}5 \cdot 83 \\
5 \cdot 50\end{array}$ \\
\hline Difference $\ldots . .$. & 0 & 0.08 & 0.09 & 0.09 & 0.22 & 0.33 \\
\hline Percentage error & 0 & 0.5 & 0.8 & 0.5 & $1 \cdot 1$ & $5 \cdot 7$ \\
\hline
\end{tabular}

The first five examples here given are typical of the errors accepted. An error, such as that given in the sixth example, is only accepted in the few cases where the determination was of a superficial layer of loose, almost dry soil. It is obvious that the same actual error is trebled when the percentage moisture falls from 15 to 5 ; moreover, such a dry soil consists largely of aggregates which are not readily broken down, and the loss of moisture which would take place during the time occupied in producing a thoroughly homogeneous mixture, will introduce a larger error than is now under consideration.

\section{The Weight of Dry Soll contained in the Cylinder.}

The total initial weight of the soil was determined by actual measurement, and the percentage moisture in each inch was then determined, and, from these, an average figure for the percentage moisture obtained. From these figures a simple calculation gives the 
dry weight. The following table gives the most divergent results obtained in numerous determinations:-

\begin{tabular}{|c|c|c|c|c|c|c|}
\hline & Date & $\begin{array}{c}\text { Actual } \\
\text { weight }\end{array}$ & $\begin{array}{c}\text { Average } \\
\text { moisture }\end{array}$ & $\begin{array}{c}\text { Dry } \\
\text { weight }\end{array}$ & Difference & $\begin{array}{c}\text { Percentage } \\
\text { error }\end{array}$ \\
\hline 1st determination \\
2nd,
\end{tabular}

The method, owing to its indirectness, is not one that admits of general adoption, and the chief reason for its use was the comparative ease with which small samples can be haudled. Its accuracy is nevertheless sufficient, for it must be noted here that the land had twice during this season been "compacted," a process which must naturally raise the weight of soil in the superficial 8 inches. The error due to the method of experiment and calculation is therefore certainly less than that given.

The second point to be noted in this procedure is the use of the temperature of $100^{\circ} \mathrm{C}$., for drying. This was adopted in place of the more usual $110^{\circ} \mathrm{C}$., as a matter of convenience. Preliminary experiments had shown that the increased loss due to the use of the higher temperature did not exceed 0.005 gram on 10 grams soil.

\section{Detalls of the Investigation.}

(A) Specific Gravity. This was determined from samples of soil dried in the following manner:-

The soil is first air dried and then reduced to fine powder in a mortar, after which it is dried in a water-bath of $100^{\circ} \mathrm{C}$, for four hours. It is then cooled in a desiccator and transferred to a dry tube when cool.

A known weight of about 10 grams of this soil is boiled with water in a small flask. After cooling to $60^{\circ} \mathrm{C}$, it is transferred to the specific gravity bottle and weighed.

Each determination is controlled by a second determination in which an unknown weight of soil, prepared and boiled as before, is transferred to the specific gravity bottle. The bottle is weighed and the contents are then transferred to an open dish, evaporated to dryness over a waterbath, and finally dried for four hours at $100^{\circ} \mathrm{C}$., in a water oven. The dish is then transferred to a desiccator, cooled and weighed. The two figures in all cases agree within an error of $1 \cdot 5$ per cent. 
A series of determinations was thus unade for each of the eight superficial inches, and the average of the duplicate determinations is here given:

Specific Gravity.

\begin{tabular}{|c|c|c|c|c|c|c|c|c|}
\hline & $\begin{array}{c}\text { Surface } \\
\text { to } 1 \text { inch }\end{array}$ & $\begin{array}{l}1-2 \\
\text { inch }\end{array}$ & $\begin{array}{l}\text { 2--3 } \\
\text { inch }\end{array}$ & $\begin{array}{l}3-4 \\
\text { inch }\end{array}$ & $\begin{array}{l}4-5 \\
\text { inch }\end{array}$ & $\begin{array}{l}5-6 \\
\text { inch }\end{array}$ & $\begin{array}{l}6-7 \\
\text { inch }\end{array}$ & $\begin{array}{l}7-8 \\
\text { inch }\end{array}$ \\
\hline $\left.\begin{array}{l}\text { Specific } \\
\text { gravity }\end{array}\right\} . .$. & $2 \cdot 716$ & $2 \cdot 715$ & $2 \cdot 713$ & $2 \cdot 710$ & $2 \cdot 706$ & $2 \cdot 736$ & $2 \cdot 734$ & $2 \cdot 734$ \\
\hline Average & \multicolumn{4}{|c|}{$2 \cdot 713$} & \multicolumn{4}{|c|}{$2 \cdot 735$} \\
\hline
\end{tabular}

The chief point of interest in the above table is the abrupt rise of specific gravity below the 5 th inch, the increase being 0.029 . So far no recorded parallel has been traced. The cause may possibly be found in the native plough, which penetrates to this depth. At least once each year the lands are thoroughly plonghed several times in each direction, but the soil is not inverted. It is possible to conceive that this repeated loosening accompanied by percolation of rain would silt out the particles of higher specific gravity from the superficial soil.

(B) Apparent Specific Gravity. For this determination a cylinder of known internal diameter and 8 inches in length was used. The methods by which the dry weight of soil contained in the cylinder was determined have already been detailed and need not be repeated here. From this figure the apparent specific gravity of the superficial 8 inches of soil is readily calculated. In these determinations a break is apparent at the 4th inch, showing the more compact nature of the soil below that depth. It will be convenient, however, to consider the superficial 5 inches together, since, as has already been shown, the increase in the actual specific gravity occurs here.

The following figures will indicate the range of value obtained for the apparent specific gravity:-

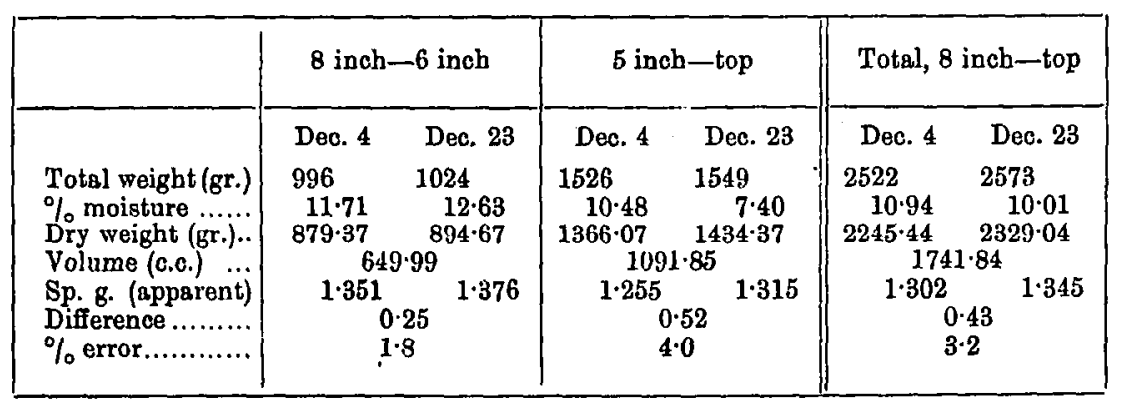


As has been already explained, these differences are, at least partly, due to the cultivation of the field during the intervening three weeks. A control determination, taken on Dec. 4th, gave the total dry weight as $2237 \cdot 4$, and the specific gravity (apparent) as 1.284 , or a working error of 1.4 per cent.

(C) Weight of Soil per Acre. This is merely a calculation from the apparent specific gravity. For these lands the weight of dry soil per acre of a layer 8 inches deep is approximately 2,400,000 lbs. The exact value for the superficial 8 inches will, of course, depend to some extent on the condition of cultivation. Thus in the sample taken on Dec. 4th the value is $2,360,253 \mathrm{lbs}$., while that for Dec. $23 \mathrm{rd}$ is $2,438,423 \mathrm{lbs}$., the mean being almost exactly $2,400,000 \mathrm{lbs}$., which figure may be taken as the average weight of soil in an acre calculated as 8 inches deep.

(D) Volume of Interstitial Space. The figure representing the volume of the interstitial space is most important, since it will indicate the maximum volume of water which could be contained in saturated soil. For this reason the value should be calculated from the values obtained for the 6 th- 8 th inch inclusive. These will approximate more nearly to the true value for the bulk of the soil. Calculated in this manner the most divergent values obtained were :-

$\left.\begin{array}{l}\text { (1) } 50 \cdot 3 \\ \text { (2) } 49 \cdot 4\end{array}\right\}$ average $49 \cdot 8$

Roughly, therefore, the interstitial space may be considered as equal to one-half the volume of the soil.

(E) Saturation Value. By this is meant the number of grams of water contained in the saturated soil, the dry weight of which is 100 grams. Throughout the following pages the figures representing moisture percentages are calculated on the dry weight. This value has not been determined experimentally, it can, however, be readily calculated from the above figures. It has been shown that the interstitial space is approximately 50 per cent., while the specific gravity (actual) of the soil is $2 \cdot 755$. This is equivalent to $36.6 \mathrm{per}$ cent. moisture on the dry weight of soil.

(F) Movement of Soil Moisture. This question is a very wide one, and the determinations now detailed only touch on the very margin of the subject. They seem, however, to indicate that this movement assumes very large proportions in these soils. The methods by which the determination of the value of soil moisture was made have already 
been detailed. It will be necessary here, therefore, only to note the general mode of investigation.

The experiments consist of two series which were carried out concurrently. In the first of these a particular area of land was submitted to various methods of culture, and the effect of these on the moisture content of the superficial 8 inches determined from samples removed at intervals. This series was commenced immediately after the cessation of the rains in October, and continued until the following February.

In the second series the moisture in the land at different stages of cultivation was determined $(a)$ in the early morning, $(b)$ about 2.30 p.m., the two samples in all cases being taken as near as possible to each other to reduce to a minimum the errors introduced by lateral variations in the value of soil moisture.

Clearly the first point to determine is the behaviour of moisture in uncultivated land. For this purpose a field was, shortly after the commencement of the rains, allowed to go out of cultivation after a preliminary course of thorough ploughing and levelling. In this condition it remained until the end of the rains, and received the last rain on October 7 th to 9 th, between which dates 2.85 inches of rain fell.

Moisture determinations were made on the following October 10th, and again on October 17th, October 23, and November 21st, the only rain received during the period was 0.3 inches, which fell on October 30 th; the field throughout the period remained untouched.

The following table shows the values obtained:-

Percentage of Water in Soil Samples.

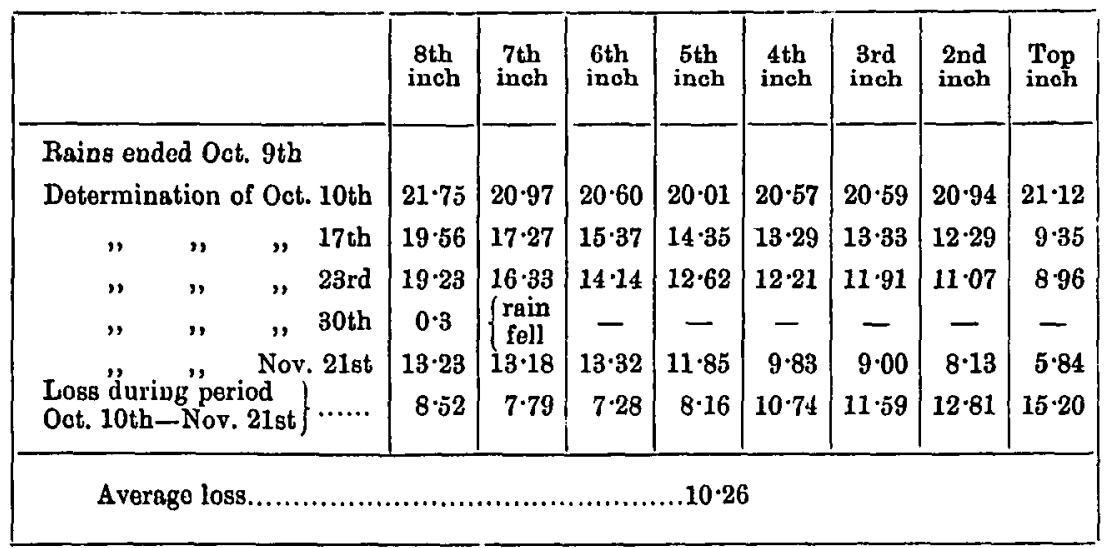

This is equivalent to a total loss of 210 tons of water per acre, or an average daily loss of 4 tons per acre. 
That this figure should represent the actual loss per acre during the period is highly improbable, and an attempt was accordingly made to obtain a nearer approximation to the real value.

The percentage of water at a given point is never stationary, and its amount must be considered as the value which results from the simultaneous action of two natural causes, ( 1 ) the motion from that point in the direction of the surface, to replace the water removed by the evaporation influence of the air, and (2) the passage of water to that point frum a lower level. It must be borne in mind that these processes may be reversed as the result of heavy rain, and the motion will then take place in the opposite direction. The following table will, however, show that in these soils the important motion is that given above. On the 23rd October two determinations were made: the first of these from a sample taken at 8 a.m., at which time evaporation had barely commenced, the second from a sample taken at 2.30 p.m., shortly after the heat of the day had passed and when evaporation might therefore be supposed to have reached a maximum:

Percentage of Water in Soil Samples.

\begin{tabular}{|r|r|r|r|r|r|r|r|r|}
\hline & 8th inch & 7th inch & 6th inch & 5th inch & 4th inch & 3rd inch & 2nd inch & Top inch \\
\hline $\begin{array}{r}\text { Morning } \\
\text { sample }\end{array}$ & 19.23 & 16.33 & $14 \cdot 14$ & $12 \cdot 62$ & $12 \cdot 21$ & 11.91 & $11 \cdot 07$ & 8.96 \\
$\begin{array}{r}\text { fternoon } \\
\text { sample }\end{array}$ & 15.60 & 14.39 & $12 \cdot 74$ & $12 \cdot 21$ & $12 \cdot 11$ & $11 \cdot 39$ & 9.86 & 4.93 \\
Loss......... & 3.63 & 1.94 & 1.40 & 0.41 & 0.10 & 0.52 & 1.21 & 4.03 \\
\hline
\end{tabular}

It will be evident from this table that the moisture lost during the day is replaced from below, in greater part, during the night.

The table also gives a close approximation to the correct value of the total daily loss. It is equivalent to a loss of 1.66 per cent. of dry weight, or 17.8 tons per acre. This is very much in excess of the figure previously obtained, and indicates a considerable recuperative power.

This figure, again, cannot be considered more than an approximation, and it is not yet apparent what the true value of the daily loss is. The following reasons briefly indicate that the loss must be in excess of this figure:-

(1) The figure obtained is the actual loss only, it must be remembered that the upward motion of the water is a continuous process 
which only becomes apparent at night, when evaporation is slight or non-existent.

(2) The second (afternoon) is taken at 2.30 p.m., when evaporation is at its maxinum. Evaporation will not cease till evening (about 6 p.m.), and this latter amount is omitted from the calculation.

(3) From the above figures it is obvious that the loss is not restricted to the superficial 8 inches, and, probably within a short distance, it would appear to be increasing with the depth.

There is here sufficient reason for supposing that, in taking the above figure-17.8 tons per acre-as the daily loss, the calculations based on it will not be open to the charge of exaggeration.

It is apparent from the figures given here that there is in these soils an enormous capability for raising water to the surface, though it is not possible at present to give an exact measure of it. The recognition of this upward motion is so important that a further proof of its existence will be given.

It has already been shown that a field, which is not tilled, rapidly and consistently loses moisture. The cause of this is to be found in the fact that there is a complete continuity of soil particles up to the surface. There is no abrupt rise in the volume of the interspaces such as occurs about the 5th inch when the land is cultivated with the native plungh. Consequently the flow of moisture from below to the surface receives no check. The effect produced by introducing such a break in continuity was the next point of enquiry. For this purpose the field was put under the system of cultivation normally adopted when indigo is to be sown, and which has been briefly described above. The field, which had up to November 21st remained untilled, was ploughed and levelled with the maira on 22nd, and again compacted with the maira on December 22nd and the moisture determined. Though the cultivation was delayed until very late, and the land had in the meanwhile been allowed to lose a large amount of the original moisture, it was by this time approaching the condition of indigo lands. These figures are now given:-

Percentage of Water in Soil Samples.

\begin{tabular}{|c|c|c|c|c|c|c|c|c|}
\hline & $\begin{array}{l}\text { 8th } \\
\text { inch }\end{array}$ & $\begin{array}{l}\text { 7th } \\
\text { inch }\end{array}$ & $\begin{array}{l}\text { 6th } \\
\text { inch }\end{array}$ & $\begin{array}{l}5 \text { th } \\
\text { inch }\end{array}$ & $\begin{array}{l}\text { 4th } \\
\text { inch }\end{array}$ & $\begin{array}{l}\text { 3rd } \\
\text { inch }\end{array}$ & $\begin{array}{l}\text { 2nd } \\
\text { incb }\end{array}$ & $\begin{array}{l}\text { Top } \\
\text { inch }\end{array}$ \\
\hline Determination of Nov. 21st & $13 \cdot 23$ & $13 \cdot 18$ & $13 \cdot 32$ & $11 \cdot 85$ & $9 \cdot 83$ & $9 \cdot 00$ & $8 \cdot 13$ & $5 \cdot 84$ \\
\hline Dec.22nd & $15 \cdot 14$ & $14: 19$ & $14 \cdot 11$ & $11 \cdot 72$ & $9 \cdot 66$ & $8 \cdot 20$ & $7 \cdot 23$ & $3 \cdot 54$ \\
\hline Gain or loss $\ldots . . . . . . \ldots \ldots \ldots$ & +1.91 & $j+1.01$ & $+0 \cdot 79$ & -0.13 & -0.17 & $-0 \cdot 80$ & -0.90 & $-2 \cdot 30$ \\
\hline
\end{tabular}


The result of cultivation has been a total loss equivalent to 0.07 per cent. of dry weight from top 8 inches. The figures, however, show that the loss is confined to the superficial 5 inches as the result of loosening the soil. Below this there is a marked rise, the value of which increases with the depth. The condition of the field is obviously much more satisfactory, but the chief point to be noticed is that the increase is due to a rise of moisture from the lower layers of the soil.

An examination of the figures for December 22nd shows no marked break in the diminution of soil moisture as the surface is approached. The diminution is gradual, and requires a comparison with previous figures to make the break at the 5th inch apparent. It appeared, therefore, that an effective break had not been introduced, and a further attempt was made to do this. For this purpose the land was ploughed four times, and finally a maira lightly mu over the surface to level without compacting the soil. The surface soil was reduced in this way to a very fine and practically air-dry condition, which, it was anticipated, would form an adequate check to evaporation. On the morning of January 18th, rain began to fall, and a sample was therefore taken and a moisture determination made. Previous determinations are quoted for comparison:-

Percentage of Water in Soil Samples.

\begin{tabular}{|c|c|c|c|c|c|c|c|c|}
\hline & $\begin{array}{l}\text { 8th } \\
\text { inch }\end{array}$ & $\begin{array}{l}\text { 7th } \\
\text { inch }\end{array}$ & $\begin{array}{l}\text { 6th } \\
\text { inch }\end{array}$ & $\begin{array}{l}\text { 5th } \\
\text { inch }\end{array}$ & $\begin{array}{l}\text { 4th } \\
\text { inch }\end{array}$ & $\begin{array}{l}\text { 3rd } \\
\text { inch }\end{array}$ & $\begin{array}{l}\text { 2nd } \\
\text { inch }\end{array}$ & $\begin{array}{l}\text { Top } \\
\text { inch }\end{array}$ \\
\hline $\begin{array}{l}\text { Dec. 19th, field ploughed } \\
\text { and levelled }\end{array}$ & & & & & & & & \\
\hline Determination of Dec. 22ud & $15 \cdot 14$ & $14 \cdot 19$ & $14 \cdot 11$ & $11 \cdot 72$ & 9.06 & 8.20 & $7 \cdot 23$ & $3 \cdot 54$ \\
\hline , , $\quad$ JRn. 18th & 21.58 & 16.23 & $13 \cdot 80$ & $10 \cdot 85$ & $9 \cdot 33$ & $7 \cdot 27$ & $4 \cdot 36$ & $7 \cdot 52$ \\
\hline Gain or loss & $+6 \cdot 44$ & $+2 \cdot 04$ & $-0 \cdot 31$ & -0.87 & -0.83 & -0.93 & $-2 \cdot 87$ & $+3 \cdot 98$ \\
\hline
\end{tabular}

Here, again, the superficial inches show a loss (the gain in the top inch being due to a rain falling at the time the sample was taken). The 7 th and 8th inch, however, show a large increase in the moisture content, equivalent to 4.24 per cent. of the dry weight. This rise is due to the reduction of evaporation, which is now so small that the upward flow can more than compensate for it. It must further be noted that the moisture contained in the 8 th inch is now equal in amount to that contained by this inch the day after a three days' rain had ceased. In the meantime three montlss had elapsed, broken only by a single shower of 0.3 incbes-three weeks after the commencement of the experiment. 
If there be needed further proof of an upward flow which is capable -in the presence of only slight evaporation from the surface-of maintaining the moisture at a value which is 60 per cent. of the saturation value, and, in the presence of excessive evaporation, very largely replacing during the night the moisture lost by evaporation during the day, it will be found in the fact that it became possible by altering the methods of cultivation, to reduce and increase at will and within wide, but so far indefinite, limits the moisture in the field. Sufficient has, however, been said to show that an upward flow of no mean order appears to be the rule in these soils.

From the figures given in the above lines it is apparent that there must be a drain of no mean order upon the moisture retained in the soil, and it becomes a matter of interest to trace to its source the supply from which this movement emanates. To a small extent, data bearing upon this problem have been accumulated. Though suggestive, their range is necessarily small, and insufficient to throw any very direct and definite light upon the subject. These preliminary notes upon one branch of the problem are now communicated in anticipation of the occurrence of un early opportunity for a renewal of the investigation upon the wider aspect. Until such opportunity occurs for dealing with this more fully the data and their interpretation must remain incomplete.

\section{Conclusion.}

The points on which an attempt has been made to lay emphasis may be summed up as follows :-

(1) A large daily evaporation is taking place from the surface of the soil.

(2) This evaporation is entirely, or in greater part, counteracted by a large upward flow of moisture from a lower level and ultimately from the ground water.

Sufficient has been said throughout the course of the paper to show that the question is.one of considerable practical importance, and it is unnecessary to dilate further on this aspect. Further work will alone decide the questions which have been indicated; possibly the more serious omissions in the above series of observations are to be found in the absence of mechanical analyses, and in the complete lack of observation of the value of soil moisture at a greater depth than 8 inches. 